\title{
Response Analysis Of The Lower Structure Of Girder Bridge With Lead Rubber Bearing (LRB) And High Damping Rubber Bearing (HDRB) Due To Earthquake Excitation
}

\author{
Donald Essen , Siti Sukainah \\ Faculty of Engineering, University Mercu Buana Jakarta, Indonesia \\ donalessenstmt@gmail.com, sitiisukainah@gmail.com
}

\begin{abstract}
Seismic isolation is a system to reduce seismic energy acting on the bridge by adding an object so-called base insulator. The purpose of this study is to obtain a comparison of dimension, damping ratio, and the lower structure response designed as a ductile component with High Damping Rubber Bearings (HDRB) and Lead Rubber Bearings (LRB). This study uses CSI BRIDGE 21 computer program. Earthquake forces analysis uses dynamic analysis with response spectra as final evaluation for the performance of lead rubber bearing and high damping rubber bearings and the load characteristics for bridges is following SNI 1725: 2016 and bridge design for earthquake load is following SNI 2833: 2016. The bridge performance is expected to no longer rely merely on the dimensions and stiffness of the pillars in response to earthquake loads, but also on LRB or HDRB as a structural device on bridge support by increasing the effectiveness of pillar stiffness in providing damping energy during an earthquake.
\end{abstract}

\section{Keywords}

base insulator, high damping rubber bearing, lead rubber bearing, Seismic isolation

\section{Introduction}

A bridge is an essential infrastructure that serves to connect two segments of road separated by obstacles, such as valley, river, ravine, irrigation and drainage channel, railroad, reservoir, and others to facilitate land transportation.

A natural disaster, like earthquakes, is one of the factors that can damage building structures. Indonesia is very prone to earthquakes due to its position on the encounter of the world's three main plates: Eurasia, Indo Australia, and Pacific. In early August 2018, an earthquake with magnitudes of 7 occurred in Lombok, West Nusa Tenggara. It proves that Indonesia has high potential and risk of earthquakes. This natural event caused a lot of damage to infrastructures, as happened to Tampes Bridge in Lombok that connects Bayan with Kayangan District, Lokok Duren Bridge that connects Kayangan and Gangga District, and LUK Bridge in Gangga District. Bridges generally get damaged in lower structures.

So far, building structural design is conventional as passive structures that only rely on stiffness and strength to bear gravity and earthquake loads. Therefore, structural performance are commonly judged by the stiffness and strength of the structure, and if it continues happen, the problem in near future is that high material demands will increase to produce a very stiff structure and eventually the construction cost will be more expensive. Technological development has created a lot of innovations that have brought positive changes in the construction world.

In recent years, base isolation has developed as a technology to design buildings and bridges in highly prone earthquake zones. The idea of base Isolation is to eliminate destruction and damage to buildings or bridges during an earthquake (Widodo et al., 2003)

Based on SNI 2833-2016 regarding earthquake resistance design codes for bridges, for force-based design, where the structure is made to behave flexure to earthquake loads and the structure is allowable to get damaged in large earthquakes but not allowable to reach failure, is by determining the structural component points with the plastic hinges meet the detailing requirements in the regulations and also outside the plastic hinge to bear shear capacity. Based on the bridge structure characteristics, construction engineers can use one of three options for an earthquake design strategy, as follows:

Type 1: ductile lower structures with elastic upper structures.

Tipe 2: elastic lower structures with ductile upper structures.

Tipe 3: elastic upper structure and lower structure with fusion mechanism on the surface between the upper and lower structures.

Base insulator types include High Damping Rubber Bearing (HDRB) and Lead Rubber Bearing (LRB). One of the bridges in Indonesia that uses Lead Rubber Bearing (LRB) is Kali Kenteng Bridge in Semarang-Solo Highway 
project. The bridge uses 2 LRB rows at the bottom of each girder with the system changed to a simple beam by a linked slab (Wahyuningsih Tri Hermani, 2019)

This thesis will analyze the comparison of Lead Rubber Bearing (LRB) and High Damping Rubber Bearing (HDRB) on Coal Hauling Road Bridge in Belayan River, Tabang, Kutai Kartanegara - East Kalimantan related to earthquake loads.

\section{Methodology}

The research method is an analytical method for the bridge structure modeling with base isolation referred to applicable regulations, like Indonesian National Standard (SNI).

This research method uses a case study analysis. Primary data collection in the form of site condition was conducted with a direct field survey by the team to the construction site and the survey results were compiled in a report. Secondary data in the form of topographic, vehicle types, and allowable loads are obtained from the project owner's archives.

The data that has been collected is then processed as material for a bridge design study, the process is predesigned with modeling and after that a structural analysis is carried out. The results of the analysis will bereported as a form of conclusions in the study. 


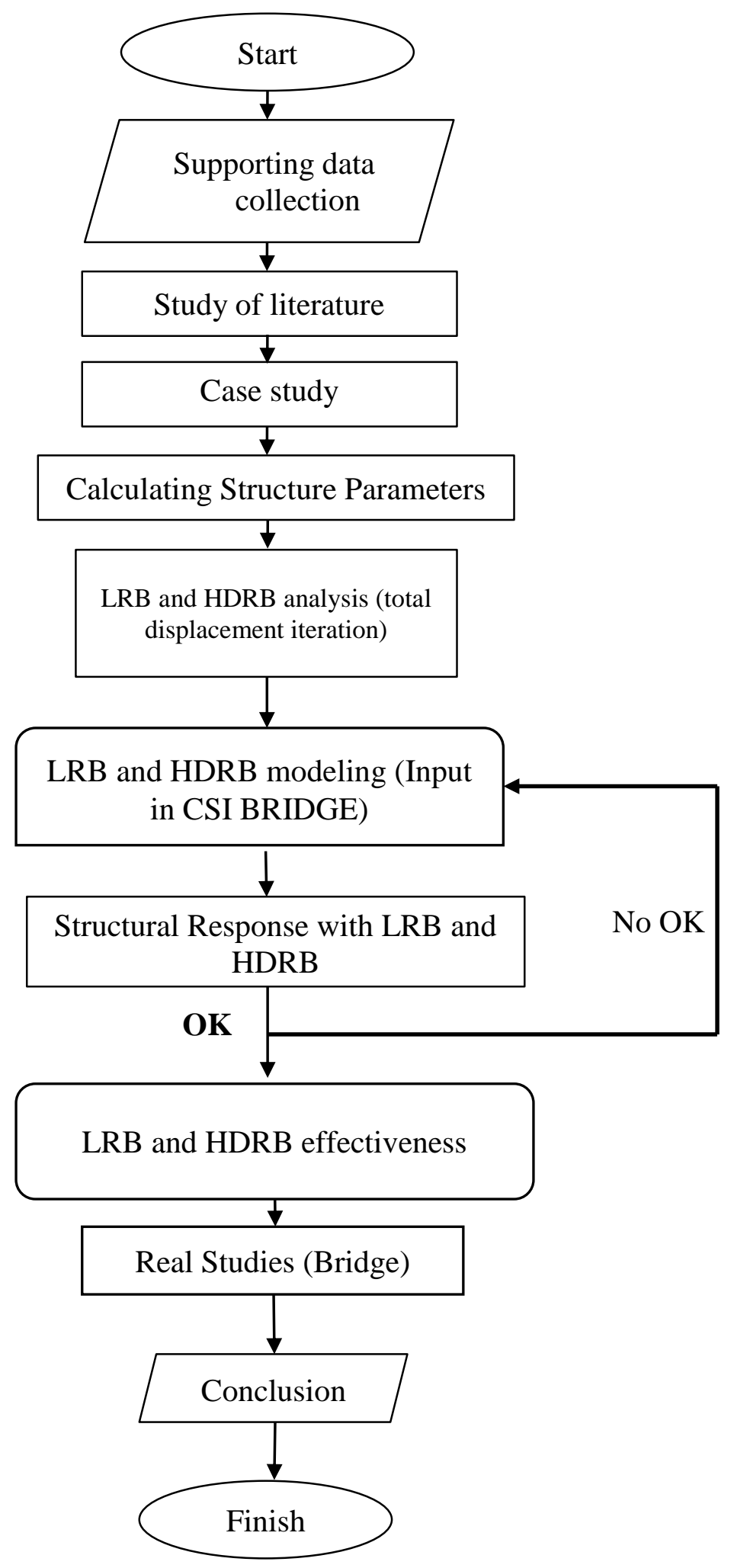

Figure 1 Research Flowchart (Flowchart)

\section{Source: Research Data}

Collection of supporting data such as:

a. Bridge profile data for building structures under the Kutai Kartanegara bridge

b. Design dimension data for Lead Rubber Bearing (LRB) and High Damping Rubber Bearing (HDRB) 
c. Relevant regulations according to SNI

d. Related books.

From this literature study, design criteria will be obtained which will be used in data processing.

Bridge Plans:

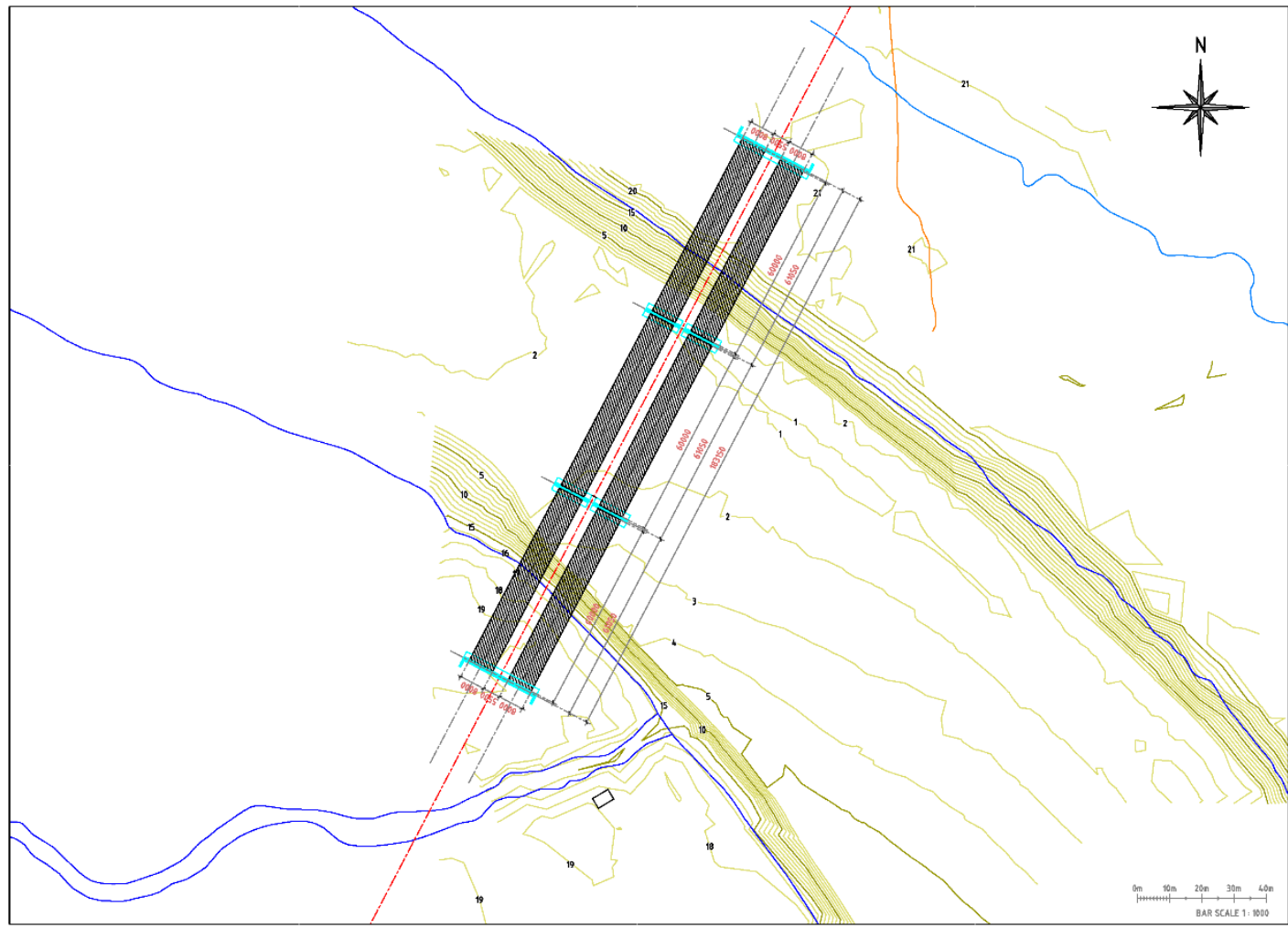

Figure 2. Bridge Plan Layout

Source: (Author's work)

This bridge has 2 spans with a continuous support with the structural model data as follows

Table 1. Data Model Structure

\begin{tabular}{ccc}
\hline NO & Description Descriptio & Mod \\
\hline 1 & Length of Span (L) & $60 \mathrm{~m}$ \\
2 & Pier height (H) m & $8 \mathrm{~m}$ \\
3 & Dim. Pierhead (b,h) & $3 \mathrm{~m} \mathrm{x} 1.7 \mathrm{~m}$ \\
4 & Dim. Diafragma (w,t) & $0.2 \mathrm{~m} \mathrm{x} 0.015 \mathrm{~m}$ \\
\hline
\end{tabular}

The structure is a continuous span bridge whose length is $60 \mathrm{~m}$. A bridge that has 2 (two) pillars with a height $($ Hpier $)=8$ meters. The bridge with a total concrete deck width of $8.5 \mathrm{~m}$, has 2 lanes with $3.5 \mathrm{~m}$ width each and is equipped with $0.5 \mathrm{~m}$ wide pedestrian access on both sides.

Is known:

1. Steel Grade SM 490 untuk U Girder $(\mathrm{Fy}=345 \mathrm{Mpa})$

2. Modulus of Elasticity $\left(\mathrm{E}_{\text {beam }}\right): 4700 * \sqrt{F c}=4700 \sqrt{30}=25700000$

3. Concrete Quality K350 untuk Pier, Deck : Fc' $=30 \mathrm{Mpa}$

4. Modulus of Elasticity $\left(\mathrm{E}_{\mathrm{pier}}\right): 4700 * \sqrt{F C}=4700 \sqrt{30}=25700000$

\section{Result and Analysis}

The model in this study is an initial design of a bridge structure with a span length and pier height which will later represent the actual model of the bridge structure. In this stage, the model is given a load in accordance with the provisions in SNI 2833/2016 and SNI 1725 2016. This bridge is assumed to be an important bridge and is in a strong earthquake area so that the structural design must provide sufficient dissipation energy so that the bridge structure can still be used after the earthquake ends. . Bridge modeling, in this stage modeling is carried out with the help of the CSi Bridge 21 program. 


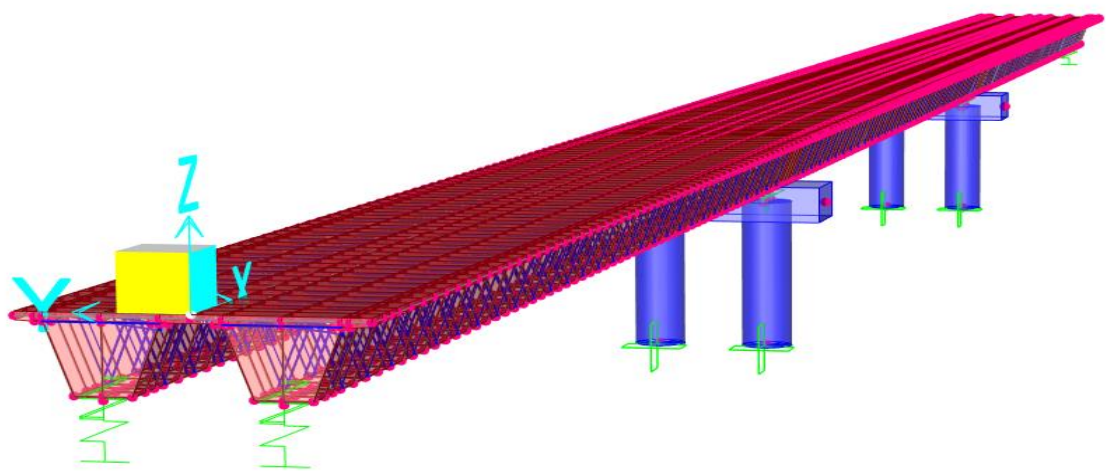

Figure 3. 3D Bridge Design

In the modeling of the girder structure it is modeled with U Shape Girder precast concrete With cross-sectional proportions:

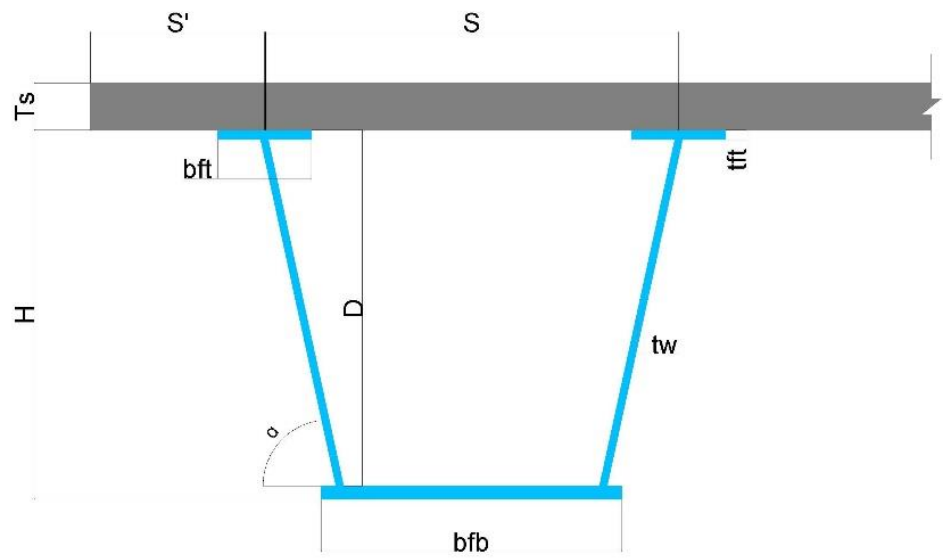

Cross Proportion:

Figure 4. Cross-section of U girder

$$
\begin{array}{lr}
\mathrm{H}=2200 \mathrm{~mm} & \alpha=71^{\circ} \\
\mathrm{D}=2150 \mathrm{~mm} & \mathrm{tf}_{\mathrm{t}}=25 \mathrm{~mm} \\
\mathrm{~S}=2800 \mathrm{~mm} & \mathrm{tw}=20 \mathrm{~mm} \\
\mathrm{bf}_{\mathrm{t}}=400 \mathrm{~mm} & \mathrm{tf}_{\mathrm{b}}=25 \mathrm{~mm}
\end{array}
$$

For strain and stress parameters modeling reinforcing steel for the purposes of curvature moment analysis refers to CALTRANS.

Table 2. Mechanical Properties of Steel

\begin{tabular}{cccc}
\hline Property & $\begin{array}{c}\text { Reinforcement } \\
\text { Size }\end{array}$ & $\begin{array}{c}\text { Parameter } \\
\text { Grade 420 }\end{array}$ & $\begin{array}{c}\text { Parameter } \\
\text { Grade 550 }\end{array}$ \\
\hline $\begin{array}{c}\text { Minimum yield stress } \\
\text { specification, f y } \\
\text { Tensile stress, fu }\end{array}$ & D10 s/d D50 & $420 \mathrm{MPa}$ & $550 \mathrm{MPa}$ \\
& D10 s/d D50 & $550 \mathrm{MPa}$ & $675 \mathrm{MPa}$ \\
\hline
\end{tabular}

From the input of earthquake response spectrum data in Padang city with soft soil conditions using Csi Bridge 21 software. As shown in Figure 5 is a spectrum response spectrum in Padang city. 


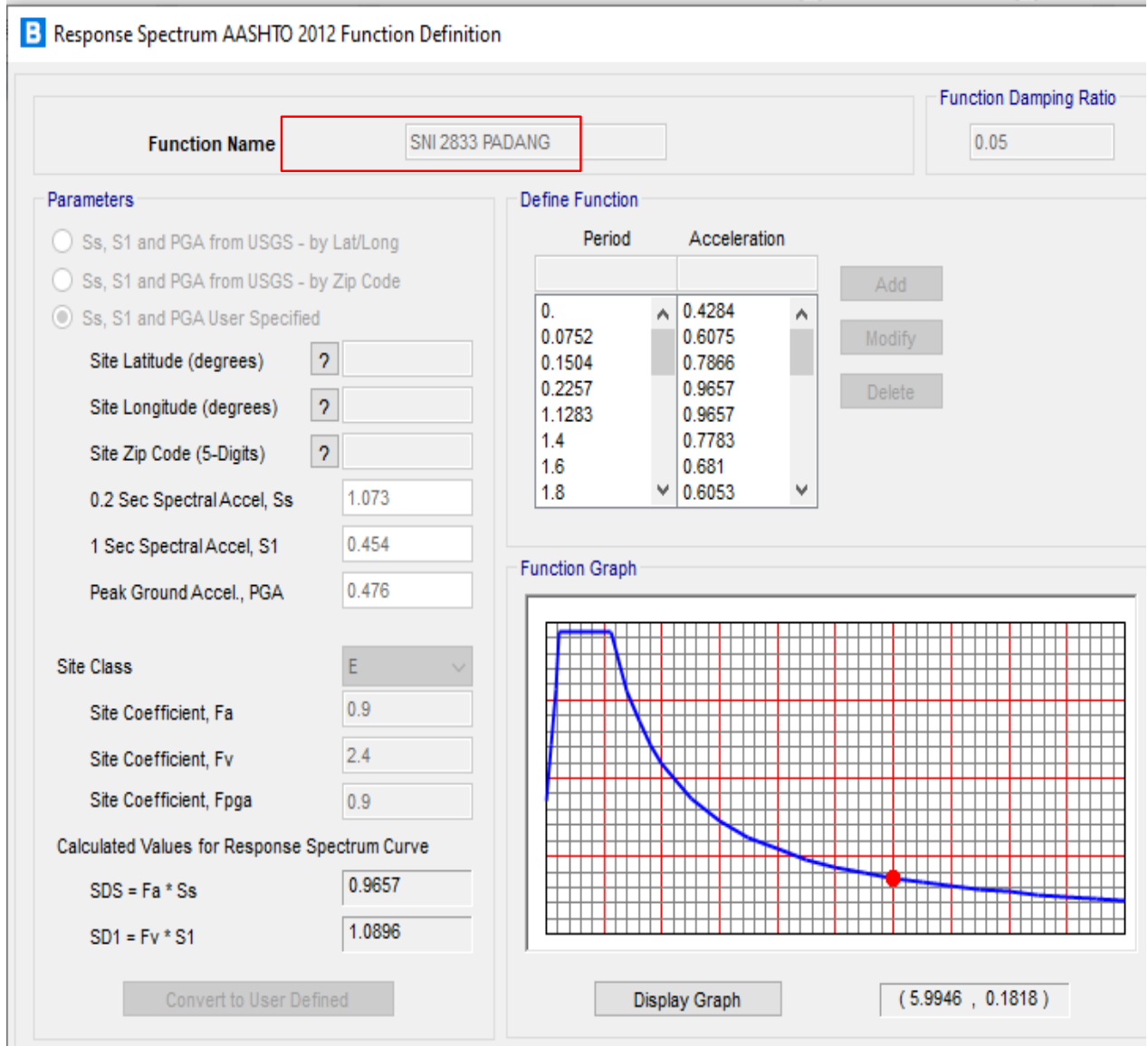

Figure 5. Response Spectra for the Padang city earthquake

Earthquake Base Shear Force

From the CSi Bridge output results, the base reaction due to the nominal earthquake is obtained, namely for the $\mathrm{X}$ or longitudinal direction of $3220,729 \mathrm{kN}$ and the $\mathrm{Y}$ or transverse direction of $7937,228 \mathrm{kN}$ as shown in Figure 6 for the $\mathrm{X}$ and $\mathrm{Y}$ directions.

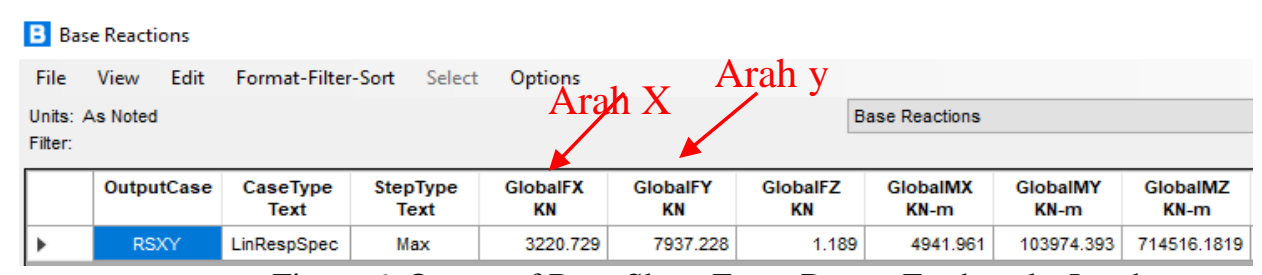

Figure 6. Output of Base Shear Force Due to Earthquake Load

In the loading analysis on the bridge structure model, a combination of loading with a factor scale is applied so that it can analyze in ultimate conditions or service conditions, as for the combination of loading The load combination used is based on SNI 1725: 2016 article 6.1. Table 3 shows the load combinations used are as follows 
Table 3. Combinations of Loads Used

\begin{tabular}{|c|c|c|c|c|c|}
\hline $\begin{array}{c}\text { Boundary } \\
\text { Conditions }\end{array}$ & $\begin{array}{l}\text { MS, } \\
\text { MA }\end{array}$ & PL & $\mathrm{EW}_{\mathrm{s}}$ & $\mathrm{EU}_{\mathrm{n}}$ & EQ \\
\hline KUAT I & $\gamma_{p}$ & 1.8 & - & $0.5 / 1.2$ & - \\
\hline KUAT II & $\gamma_{p}$ & 1.4 & - & $0.5 / 1.2$ & - \\
\hline EKSTRIM I & 1.0 & $\gamma_{E Q}$ & - & - & 1.0 \\
\hline LAYAN I & 1.0 & 1.0 & 0.588 & $1.0 / 1.2$ & - \\
\hline LAYAN II & 1.0 & 1.3 & - & $1.0 / 1.2$ & - \\
\hline LAYAN III & 1.0 & 0.8 & - & 1.0/1.2 & - \\
\hline LAYAN IV & 1.0 & - & 1.372 & $1.0 / 1.2$ & - \\
\hline
\end{tabular}

In CSi Bridge modeling, LRB is modeled in the form of general links at the upper and lower building structure placement boundaries.

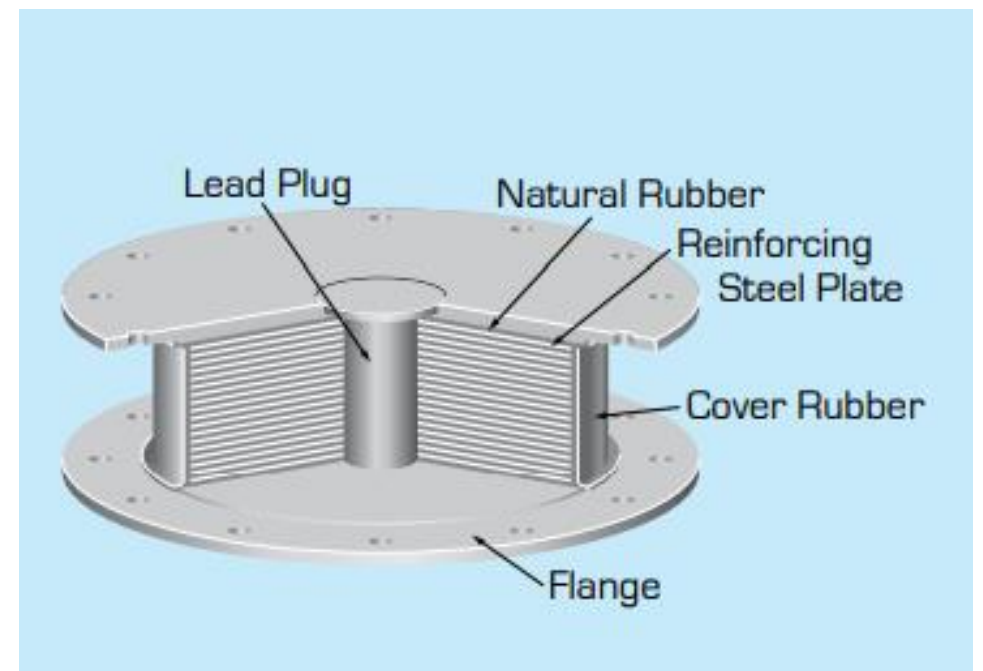

Figure 7. 3D Lead Rubber Bearing View (Source: Bridgestone)

Lead Rubber Bearing modeling uses products from Bridgestone with the following dimensions 
Table 4. Section Properties LRB1100

\begin{tabular}{|c|c|c|}
\hline Information & Size & Unit \\
\hline Type & LRB1100 & - \\
\hline Diameter (D) & 1100 & $\mathrm{~mm}$ \\
\hline $\begin{array}{l}\text { Bonded length parallel to traffic } \\
\qquad\left(a_{b}\right)\end{array}$ & 1050 & $\mathrm{~mm}$ \\
\hline $\begin{array}{l}\text { Bonded length perpendicular to } \\
\text { traffic }\left(\mathrm{b}_{\mathrm{b}}\right)\end{array}$ & 1050 & $\mathrm{~mm}$ \\
\hline Rubber area $\left(\mathrm{A}_{\mathrm{r}}\right)$ & 848544 & $\mathrm{~mm}^{2}$ \\
\hline Bearing height $(\mathrm{h})$ & 314.2 & $\mathrm{~mm}$ \\
\hline $\begin{array}{c}\text { Number of internal elastomer } \\
\text { layer }\left(\mathrm{n}_{\mathrm{p}}\right)\end{array}$ & 26 & - \\
\hline $\begin{array}{l}\text { Thickness of reinforcement steel } \\
\text { plate }\left(t_{p}\right)\end{array}$ & 4.4 & $\mathrm{~mm}$ \\
\hline $\begin{array}{l}\text { Yield strength of reinforcement } \\
\text { steel plate }\left(f_{y}\right)\end{array}$ & 240 & Mpa \\
\hline $\begin{array}{l}\text { Tensile strength of reinforcement } \\
\text { steel plate }\left(f_{u}\right)\end{array}$ & 370 & Mpa \\
\hline $\begin{array}{c}\text { Number of internal elastomer } \\
\text { layer }\left(\mathrm{n}_{\mathrm{i}}\right)\end{array}$ & 25 & - \\
\hline $\begin{array}{c}\text { Thickness of internal elastomer } \\
\text { layer }\left(\mathrm{h}_{\mathrm{ri}}\right)\end{array}$ & 7.4 & $\mathrm{~mm}$ \\
\hline $\begin{array}{l}\text { Total Thickness of internal } \\
\text { elastomer layer }\left(\mathrm{h}_{\mathrm{rti}}\right)\end{array}$ & 185 & $\mathrm{~mm}$ \\
\hline $\begin{array}{c}\text { Thickness of outer elastomer } \\
\text { layer }\left(\mathrm{h}_{\mathrm{ro}}\right)\end{array}$ & 7.4 & $\mathrm{~mm}$ \\
\hline $\begin{array}{l}\text { Total Thickness of outer } \\
\text { elastomer layer }\left(\mathrm{h}_{\mathrm{rto}}\right)\end{array}$ & 14.8 & $\mathrm{~mm}$ \\
\hline Total elastomer thickness $\left(\mathrm{h}_{\mathrm{rt}}\right)$ & 199.8 & $\mathrm{~mm}$ \\
\hline Shear Modulus of elastomer ( $\mathrm{G}$ ) & 0.385 & Mpa \\
\hline Bulk Modulus of elastomer (K) & 3100 & Mpa \\
\hline Zone & A & Mpa \\
\hline
\end{tabular}

In modeling the LRB in the CSi Bridge program, several parameters are used. The LRB parameter is obtained through previous calculations. The table shows the LRB parameters for the abutments and bridge pillars.

Tabel 5 Rekapitulasi Parameter LRB pada CSI BRIDGE

\begin{tabular}{ccc}
\hline Parameter & Pilar & Unit \\
\hline Diameter $(\mathrm{D})$ & 1100 & $\mathrm{~mm}$ \\
High $(\mathrm{H})$ & 199.8 & $\mathrm{~mm}$ \\
Post yield stiffness $\left(\mathrm{K}_{\mathrm{d}}\right)$ & 1775.95 & $\mathrm{~N} / \mathrm{mm}$ \\
Compressive stiffness $\left(\mathrm{K}_{\mathrm{v}}\right)$ & 5604536.027 & $\mathrm{~K}_{\mathrm{N}} / \mathrm{m}$ \\
Equivalent damping ratio $\left(\mathrm{H}_{\mathrm{eq}}\right)$ & 0.306 & - \\
\hline
\end{tabular}

The results of the analysis input from the CSi Bridge program are obtained as follows

Table 6. Comparison of the results of the Lead Rubber Bearing analysis

\begin{tabular}{cccc}
\hline Diameter $(\mathrm{D})$ & LRB900 & LRB1000 & LRB1100 \\
\hline Post yield stiffness $\left(\mathrm{K}_{\mathrm{d}}\right)$ & $1071.80 \mathrm{~N} / \mathrm{mm}$ & $1459.07 \mathrm{~N} / \mathrm{mm}$ & $1775.95 \mathrm{~N} / \mathrm{mm}$ \\
Compressive stiffness $\left(\mathrm{K}_{\mathrm{v}}\right)$ & 3798530.40 & $4611109.57 \mathrm{kN} / \mathrm{m}$ & $5604536.027 \mathrm{kN} / \mathrm{m}$ \\
& $\mathrm{kN} / \mathrm{m}$ & & \\
& 0.227 & 0.317 & 0.306 \\
\hline
\end{tabular}

In the High Damping Rubber Bearing analysis, the calculation steps for the design parameters are the same as for lead rubber bearings referring to the provisions of the Specification for Seismic Isolation Design AASHTO LRFD Brigde-2017 and Guide Specification for Seismic Isolation Design, 2012. The design used in modeling is the circular type (Circular Bearing). As for the products themselves, using Bridgestone. 
Table 7. Section Properties HDRB1100

\begin{tabular}{|c|c|c|}
\hline Information & Size & Unit \\
\hline Type & LRB 1100 & - \\
\hline Diameter (D) & 1100 & $\mathrm{~mm}$ \\
\hline $\begin{array}{l}\text { Bonded length parallel to traffic } \\
\qquad(\mathrm{ab})\end{array}$ & 1050 & $\mathrm{~mm}$ \\
\hline $\begin{array}{l}\text { Bonded length perpendicular to } \\
\text { traffic }(\mathrm{bb})\end{array}$ & 1050 & $\mathrm{~mm}$ \\
\hline Rubber area (Ar) & 848544 & $\mathrm{~mm} 2$ \\
\hline Bearing height $(\mathrm{h})$ & 314.2 & $\mathrm{~mm}$ \\
\hline $\begin{array}{c}\text { Number of internal elastomer } \\
\text { layer (np) }\end{array}$ & 26 & - \\
\hline $\begin{array}{l}\text { Thickness of reinforcement steel } \\
\text { plate (tp) }\end{array}$ & 4.4 & $\mathrm{~mm}$ \\
\hline $\begin{array}{l}\text { Yield strength of reinforcement } \\
\text { steel plate (fy) }\end{array}$ & 240 & Mpa \\
\hline $\begin{array}{l}\text { Tensile strength of reinforcement } \\
\text { steel plate ( fu) }\end{array}$ & 370 & Mpa \\
\hline $\begin{array}{c}\text { Number of internal elastomer } \\
\text { layer (ni) }\end{array}$ & 25 & - \\
\hline $\begin{array}{c}\text { Thickness of internal elastomer } \\
\text { layer (hri) }\end{array}$ & 7.4 & $\mathrm{~mm}$ \\
\hline $\begin{array}{l}\text { Total Thickness of internal } \\
\text { elastomer layer (hrti) }\end{array}$ & 185 & $\mathrm{~mm}$ \\
\hline $\begin{array}{l}\text { Thickness of outer elastomer } \\
\text { layer (hro) }\end{array}$ & 7.4 & $\mathrm{~mm}$ \\
\hline $\begin{array}{l}\text { Total Thickness of outer } \\
\text { elastomer layer (hrto) }\end{array}$ & 14.8 & $\mathrm{~mm}$ \\
\hline Total elastomer thickness (hrt) & 199.8 & $\mathrm{~mm}$ \\
\hline $\begin{array}{l}\text { Shear Modulus of elastomer } \\
\text { (Geq) }\end{array}$ & 0.484 & Mpa \\
\hline Bulk Modulus of elastomer (K) & 3100 & Mpa \\
\hline Zone & A & Mpa \\
\hline Rubber Material & $\mathrm{X} 0.6 \mathrm{R}$ & - \\
\hline
\end{tabular}

Comparative Results Analysis of elastomeric bearing, Lead Rubber Bearing (LRB) and High Damping Rubber Bearing (HDRB). From the analysis using the CSI BRIDGE program, the comparison results of elastomeric bearing, lead rubber bearing (LRB) and high damping rubber bearing (HDRB) are as follows

Table 8. Comparative results of force analysis in elastomeric bearings, LRB and HDRB of pier 1 column

\begin{tabular}{|c|c|c|c|}
\hline & ELASTOMERIC BEARING & LRB & HDRB \\
\hline $\mathrm{Pu}$ & $\begin{array}{c}-2894.329 \mathrm{kN} \\
\text { (Tarik) }\end{array}$ & $\begin{array}{l}2578.614 \mathrm{kN} \\
\text { (Tekan) }\end{array}$ & $\begin{array}{l}1819.956 \mathrm{kN} \\
(\text { Tekan) }\end{array}$ \\
\hline M2 (Arah transversal) & $7633.658 \mathrm{kN} / \mathrm{m}(\mathrm{R}=3.5)$ & $\begin{array}{c}7741.043 \mathrm{kN} / \mathrm{m} \\
(\mathrm{R}=1.75)\end{array}$ & $\begin{array}{c}9002.402 \mathrm{kN} / \mathrm{m} \\
(\mathrm{R}=1.75)\end{array}$ \\
\hline M3 (Arah Longitudinal) & $12368.659 \mathrm{kN} / \mathrm{m}(\mathrm{R}=2)$ & $\begin{array}{l}4357.447 \mathrm{kN} / \mathrm{m} \\
\quad(\mathrm{R}=1.5)\end{array}$ & $\begin{array}{c}5378.964 \mathrm{kN} / \mathrm{m} \\
(\mathrm{R}=1.5)\end{array}$ \\
\hline Gaya Geser Major (V2) & 6850.372 & 4049.701 & 4796.751 \\
\hline Gaya Geser Minor (V3) & 6850.478 & 4049.775 & 4796.542 \\
\hline Diameter $(\mathrm{D}$ & $2 \mathrm{~m}$ & $1100 \mathrm{~mm}$ & $1100 \mathrm{~mm}$ \\
\hline Jumlah Tulangan & $122 \mathrm{D} 25$ & 79D25 & $101 \mathrm{D} 25$ \\
\hline
\end{tabular}


E-ISSN: 2685-3272 | P-ISSN 1412-0860

Table 9. Comparative results of force analysis in elastomeric bearings, LRB and HDRB of pier 2 column ELASTOMERIC BEARING LRB HDRB

\begin{tabular}{cccc}
\hline $\mathrm{Pu}$ & $-2836.21 \mathrm{kN}$ & $2637.579 \mathrm{kN}$ & $1877.697 \mathrm{kN}$ \\
$($ Tarik $)$ & $($ Tekan $)$ & $\begin{array}{c}\text { Tekan }) \\
8984.264 \mathrm{kN} / \mathrm{m} \\
(\mathrm{R}=1.75)\end{array}$ \\
M2 (Arah transversal) & $7880.403 \mathrm{kN} / \mathrm{m}(\mathrm{R}=3.5)$ & $(\mathrm{R}=1.75)$ & $5376.227 \mathrm{kN} / \mathrm{m}$ \\
& & $4355.236 \mathrm{kN} / \mathrm{m}$ & $(\mathrm{R}=1.5)$ \\
M3 (Arah Longitudinal) & $12357.427 \mathrm{kN} / \mathrm{m}(\mathrm{R}=2)$ & $(\mathrm{R}=1.5)$ & 4805.152 \\
Gaya Geser Major (V2) & & 4058.438 & 4804.945 \\
Gaya Geser Minor (V3) & 6866.808 & 4058.512 & $1100 \mathrm{~mm}$ \\
Diameter (D) & 6866.912 & $1100 \mathrm{~mm}$ & $101 \mathrm{D} 25$ \\
Jumlah Tulangan & $2 \mathrm{~m}$ & $79 \mathrm{D} 25$ & \\
\hline
\end{tabular}

Table 10. Comparison of LRB and HDRB

\begin{tabular}{ccc}
\hline KOMPARASI & LRB & HDRB \\
\hline Diameter $(\mathrm{D})$ & $1100 \mathrm{~mm}$ & $1100 \mathrm{~mm}$ \\
Shear Modulus $(\mathrm{G})$ & $0.385 \mathrm{Mpa}$ & $0.484 \mathrm{Mpa}$ \\
Post yield stiffness $\left(\mathrm{K}_{\mathrm{d}}\right)$ & $1775.95 \mathrm{~N} / \mathrm{mm}$ & $1294.15 \mathrm{~N} / \mathrm{mm}$ \\
Compressive stiffness $\left(\mathrm{K}_{\mathrm{v}}\right)$ & $5604536.027 \mathrm{kN} / \mathrm{m}$ & $5604536.027 \mathrm{kN} / \mathrm{m}$ \\
& & \\
Equivalent damping ratio $\left(\mathrm{H}_{\mathrm{eq}}\right)$ & 0.306 & 0.2203 \\
\hline
\end{tabular}

\section{Conclussion}

1. The behavior of LRB (Lead Rubber Bearing) and HDRB (High Damping Rubber Bearing) is highly dependent on the load and working deformation. The main parameter that greatly influences the behavior of LRB and HDRB is the shear strain, where the shear strain that occurs in the LRB comes from axial force, shear deformation force and rotation.

2. LRB and HDRB are effective for carrying strong earthquake loads by allowing relatively large shear deformations compared to using elastomeric bearings.

3. LRB can be used as an insulator that can reduce earthquake forces where the effective damping is very dependent on the characteristic strength of the lead component. Meanwhile, the effective damping of HDRB really depends on the characteristic strength of the rubber.

4. From the study conducted, it was found that the effective damping ratio for LRB was $30.6 \%$ while for HDRB it was $22.03 \%$ for the same diameter of LRB and HDRB.

5. The damping ratio of the LRB (Lead Rubber Bearing) is greater than the damping ratio of HDRB (High Damping Rubber Bearing). So that the use of LRB is more effective than HDRB.

\section{Recommendation}

The suggestions that can be derived from this research are:

1. For more detail, the next study uses a non-linear time history analysis.

2. Hysteresis modeling for HDRB needs to be reviewed in more depth.

3. Calculate the draft cost budget to compare construction cost savings using LRB and HDRB.

\section{References}

Wahyuningsih Tri Hermani (2019) 'Bridge construction cost saving from using LRB (Lead Rubber Bearing) in the area prone to earthquake, Kenteng bridge case study', in E3S Web of Conferences. EDP Sciences, p. 5018.

Widodo, W. et al. (2003) 'Elevated growth CO2 delays drought stress and accelerates recovery of rice leaf photosynthesis', Environmental and Experimental Botany, 49(3), pp. 259-272. 